\title{
ITGB3 Gene
}

National Cancer Institute

\section{Source}

National Cancer Institute. IT GB3 Gene. NCI Thesaurus. Code C38954.

This gene plays a role in the mediation of platelet aggregation and wound repair. 